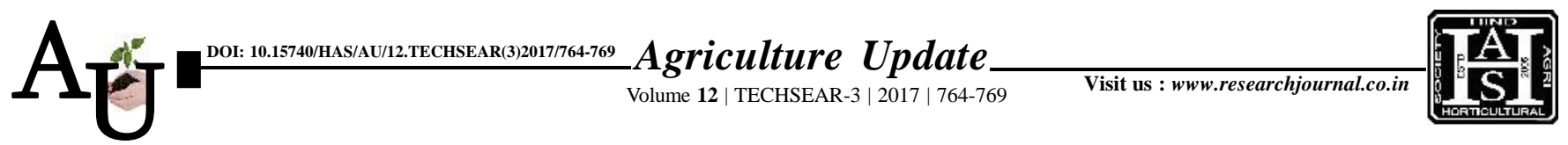

a e ISSN-0976-6847

\title{
Rевевкин автісі: A quantitative analysis of demand for tractors in India
}

Article Chronicle:

Received :

10.07.2017;

Accepted :

25.07.2017

\section{KeY WoRDS:}

Tractor, Growth rates, Demand,

Determinants
SUMMARY : India is an agricultural country. Higher productivity and greater output are the two major contributions in farm mechanization of any country. Tractors form an integral part of farm mechanization and have a crucial role to play in increasing agricultural productivity. The secondary data required for the study during the period 1974-75 to 2011-12 was collected mainly from Statistical Abstract of Punjab and Statistical Abstract of India. The study was carried out by employing tabulation with the compound growth rates and regression analysis for determining the factors responsible for increasing demand of tractors in the country. The analysis of annual compound growth rate of tractors in India showed that the growth rate was 12.55 per cent during Period I (1974-75 to1994-95) and it declined to 6.24 per cent in Period II (1995-96 to 2010-11). The regression analysis indicated that in the initial period (during 197475 to 1994-95) and overall period (1974-75 to 2010-11) of tractorisation, area under high yielding variety and gross irrigated area were significant factors determining the demand for tractors in the country. But, of late, during (1995-96 to 2010-11) social factors involved in owning tractor came out to be important variable.

How to cite this article : Baregal, Vanusha and Grover, D.K. (2017). A quantitative analysis of demand for tractors in India. Agric. Update, 12(TECHSEAR-3) : 764-769; DOI: 10.15740/HAS/AU/12.TECHSEAR(3)2017/ 764-769.
Author for correspondence :

VANUSHA BAREGAL

Agriculture Application

Technological Research Institute (ATARI), HYDERABAD

(TELANGANA) INDIA

Email : vanushabaregal@

live.com

See end of the article for authors' affiliations 